\title{
COMPARATIVE STUDIES OF SOME LONG STAPLE COTTONS AT DIFFERENT LOCATIONS
}

\author{
EL-ADLY, H.H., H.S. KHALIFA and S.R.N. SAID \\ Cotton Research Institute, ARC, Giza, Egypt
}

(Manuscript received 8 October 2013)

\begin{abstract}
Comparative studies for thirty eight genotypes descending from twenty one crosses and the two check varieties Giza 90 and Giza 80 were included in Trial A at Seds Agricultural Experimental Station in 2012 season, eighteen genotypes descending from sixteen crosses and the two check varieties Giza 90 and Giza 80 were grown in Trial B at five locations in Middle and Upper Egypt in the same season. The results obtained from Trial A showed that the strains $H^{5} 118 / 2011$ and $H^{5} 124 / 2011$ of the cross (G 83 Rad. $x$ Aust.) $x \mathrm{G} \mathrm{91,} \mathrm{H}^{5} 128 / 2011$ and $H^{5} 129 / 2011$ cross [(G $80 \times$ Aust) $x$ G 83], $H^{5} 150 / 2011$ cross (G 83rad $\times$ Kar) $\times$ [(G $83 \times$ G 80) $\times$ G 89], $H^{6} 198 / 2011$ cross[[(G $83 \times$ G 80) x G 89] x (G $83 \times$ Delta Pine)]], $H^{7} 215 / 2011$ cross [(G $\left.\left.83 \times \mathrm{G} \mathrm{80}\right) \times \mathrm{G} 89\right] \times$ Aust, $H^{8} 238 / 2011$ cross (Dand. Rad x Karsh), $\mathrm{H}^{9} 244 / 2011$ cross [G $90 \times$ Pima S62 (24240)], $H^{9} 253 / 2011$ cross [G $91 \times$ Pima S62 (24240)], $H^{10} 268 / 2011$ [G $83 \times$ (G 72 x Dand.) x G 91], H $^{11} 281 / 2011$ [G 83 x (G 72 x Dand.) x G $85]$ and Breeder1 of the promising cross [G $83 \times(G 72 \times 5844)] \times$ $G$ 80] recorded significant higher seed cotton yield (SCY) and lint cotton yield (LY) compared with the check varieties Giza 90 and Giza 80. While the crosses [(G $85 \times$ G 83) x G 90], [( $83 \times$ × 80$) \times$ $G$ 89] $x$ Aust, C.B $58 \times \mathrm{G} 90, \mathrm{H}^{8} 249 / 2010$ descending from the crosses G 91 x Pima S62 (24202), [G 83 x (G $75 \times 5844) \times$ G 91], [(G $83 \times$ G 72) $\times$ Dand] $\times$ G 85 respectively and breeder2 of the promising cross (Giza90 $\times$ Aus) had higher seed and lint cotton yield (SCY and LY) compared with the check varities Giza 90 and Giza 80 in Trial B. The mean squares of the genotypes in Trial A were highly significant for all yield components traits. Combined mean squares results in Trial $B$ of the genotypes $(G)$ were highly significant and significant for all yield traits except for lint index (LI). Environments (E) mean squares were highly significant for all studied yield traits. Genotypes-environments interactions ( $\mathrm{G} \times \mathrm{E}$ ) mean squares were highly significant for all yield traits except for lint percentage (L\%) which showed significant combined mean squares, indicating change in performance of genotypes from one location to another. In other words, the rank of a genotype differed from one location to another. High heritability estimates in broad sense ( $h_{\text {.b.s }} \%$ ) were computed for all yield traits in Trial $A$, indicated that the environment had slightly influence on these traits. Broad sense heritability estimates ( $h_{\text {.b.s }} \%$ ) for yield traits in Trial B were low for seed cotton yield (SCY), lint yield (LY) and boll weight (BW), indicated that the environmental factors had effect on these traits. On the other hand, lint percentage $(L \%)$, seed index (SI) and lint index (LI) recorded high heritability estimates in broad sense ( $h_{\text {.b.s }} \%$ ) (more than 50\%), indicating that environment had considerable effect on these traits.. The G.C.V \%
\end{abstract}


values ranged from $2.54 \%$ for lint index (LI) to $61.65 \%$ for lint yield (LY) in Trial A and ranged from 3.98\% for lint percentage (L $\%)$ to $50.0 \%$ for lint yield (LY) in Trial B. These values indicated variable environmental effects on all studied traits.

\section{INTRODUCTION}

The progress of any breeding programme depends on available genetic variation to produce new superior cotton varieties that can replace the existing ones. Introduction of new varieties are the most important objective of the cotton research programme carried out in the Cotton. Research Institute using artificial hybridization between the desired genotypes, followed by the pedigree method of selection.

The promising and desired families in the fifth generation of the different crosses were tested in the preliminary strain test (Trial A), along with the cultivars Giza 90 and Giza 80. The families selected in Trial A were tested through the advanced strain test Trial B beside the cultivated varieties Giza 90 and Giza 80 for comparison at different locations to study their performance under different environments. The superior crosses over cultivated varieties will be grown in another programme for increasing enough seeds to produce the breeder seed.

Several workers studied the performace of cotton genotypes under different environments, i.e El-Faki et al (2002), Mohamed et al. (2003), Nazmy et al. (2005), El-Adly et al. (2010) and Samia, E. Ali et al. (2012).

The main objective of this investigation was to evaluate the genotypes of 21 crosses in Trial A and 16 crosses in Trial B to recognize the promising cross which surpassed the commercial varieties for some major yield components and fiber quality traits.

\section{MATERIALS AND METHODS}

This investigation was conducted during 2012 season through the two experimental designs preliminary yield trait of trial $A$ and the advanced yield trial $B$. Trial A consisted of 40 genotypes, 38 lines descended from 21 crosses and the two check varieties, Giza 90 and Giza 80. It was grown at Seds Experimental Station, Agricultural Research Center (Table 1). While Trial B was cultivated at five locations represented Middle and Upper Egypt regions i.e Seds, El-Fayoum, El-Menia, Assuit and Sohage. Each Trial consisted of 20 genotypes, 18 lines descending from 16 crosses and the two commercial varieties Giza 90 and Giza 80 (Table2).

Experimental design of Trial $A$ and Trial $B$ in all locations were randomized complete block design with six replications; each plot consisted of five rows. The row was four 
meters long, $60 \mathrm{~cm}$ apart and $20 \mathrm{~cm}$ between hills. Standard cultural practices were applied as recommended for growing cotton. The hills were thinned to two plants each. The middle three rows of each plot were hand harvested to determine seed cotton yield (SCY) in Kentar / feddan and lint yield (LY) in Kentar / feddan. A random sample of 50 bolls was harvested to estimate boll weight (BW), lint percentage (L \%), seed index (SI) and lint index (LI).

\section{The following traits were investigated:}

\section{A. Yield components:}

1. Seed cotton yield (SCY.Kan/fed). estimated as weight of seed cotton yield in Kantar / faddan.

2. Lint cotton yield(LY. Can/fad).measured as average weight of lint yield in Kantar / faddan.

3. Boll weight (BW). the average weight estimated from 50 bolls picked at random from the first and fifth row of each plot.

4. Lint percentage (L\%). calculated as the relative amount of lint in a seed cotton sample, expressed in percentage.

$$
L \%=\frac{\text { w eight of lint cotton in sample }}{\text { w eight of seed cotton }} \times 100
$$

5. Seed index (SI). estimated as average weight of 100 seeds in grams.

6. Lint index (LI). estimated as average weight in grams of lint born by 100.seed.

$$
L I=\frac{S I x L \%}{(100-L \%)}=\frac{\text { seed index } x \text { lint percentage }}{(100-\text { lint percentage })}
$$

\section{B- Fiber properties.}

Fiber physical properties:

1- Upper half mean length (m.m) UHM and, Fiber uniformity index (UI) were determined using the fibrograph 630 according to (ASTM D: 1447-67).

2- Fiber strength and elongation percentage (Y.St) were determined on the Stelometer Tester according to the standard methods of (ASTM D: 144567).

3- Micronaire reading (Mic). was estimated using Micronaire 275 instrument according to [ASTM D: 1448-2006]. 
All fiber properties were tested in Cotton Technology Research Division labs; Cotton Research Inst. (C.R.I.) under constant conditions of temperature $\left(20 \pm 2^{\circ} \mathrm{C}\right)$ and relative humidity ( $65 \pm 5 \%)$ according to HVI Instrument.

The analysis of variance was calculated by using the methods mentioned by Sendecor (1965) and Le Clerg et al. (1962).

\section{RESULTS AND DISCUSSION}

The main objective of this study was to evaluate 38 new strains descended from 21 crosses in Trial A and 18 strains belonging to 16 crosses in Trial B. The check varieties were Giza 90 and Giza 80 as control through Trial A and Trial B. Differences between the tested strains were detected for yield, yield components and fiber properties compared with the check varieties Giza 90 and Giza 80.Table (1) showed that the mean squares of the genotypes in Trial A were highly significant for all yield components traits. These results are in agreement with those obtained by El-Feki et al. (2005), Mohamed et al. (2005) and El-Adly et al. (2006).

The results of the combined analysis of variance for all yield component traits in Trial B are shown in Table (2). Mean squares of the genotypes (G) were highly significant and significant for all yield traits except for lint index (LI), indicated the presence of large variations among these traits. Environments (E) mean squares were highly significant for all studied yield traits. Genotypes-environments interactions ( $\mathrm{G} x$ E) mean squares were highly significant for all yield traits except for lint percentage (L\%) which showed significant combined mean squares, indicating change in performance of genotypes from one location to another. In other words, the rank of a genotype differed from one location to another. These findings agree with those obtained by El-Amen et al. (2004) and El-Adly et al. (2010).

Table 1 Mean squares of genotypes for yield components under study.

\begin{tabular}{|c|c|c|c|c|c|c|c|}
\hline \multirow{2}{*}{ Sources } & \multirow{2}{*}{ df } & \multicolumn{6}{|c|}{ Traits } \\
\cline { 4 - 8 } & & SCY & LY & BW & L\% & SI & LI \\
\hline Rep. & 5 & $2326817.0^{* *}$ & $332308.0^{* *}$ & 104.71 & 1.3300 & 1.0402 & 0.4179 \\
\hline Genotypes (G) & 39 & $448740.0^{* *}$ & $67377.67^{* *}$ & $234.78^{* *}$ & $2.9043^{* *}$ & $2.414^{* *}$ & $1.094^{* *}$ \\
\hline Error & 195 & 229509.9 & 32865.7 & 82.29 & 1.5582 & 0.4855 & 0.2931 \\
\hline
\end{tabular}

$*, * *$ significant and highly significant at $0.5 \%$ and $0.1 \%$ levels of probability, respectively. 
Table 2. Mean squares of genotypes for yield components traits over locations under study.

\begin{tabular}{|c|c|c|c|c|c|c|c|}
\hline \multirow{2}{*}{ Sources } & \multirow{2}{*}{ df } & \multicolumn{7}{|c|}{ Traits } \\
\cline { 3 - 8 } & & SCY & LY & BW & L\% & SI & LI \\
\hline Rep.W. & 5 & $3949655.0^{* *}$ & $601256.3^{* *}$ & $154.09^{* *}$ & 1.4 & $0.7^{* *}$ & $0.4^{* *}$ \\
\hline Genotypes (G) & 19 & $522907.7^{* *}$ & $95140.5^{* *}$ & $160.10^{* *}$ & $4.9^{* *}$ & $1.3^{*}$ & 0.6 \\
\hline Environments (E) & 4 & $1431669.8^{* *}$ & $2435723.0^{* *}$ & $10488.53^{* *}$ & $26.5^{* *}$ & $17.9^{* *}$ & $5.1^{* *}$ \\
\hline G x E. & 76 & $312386.8^{* *}$ & $53719.18^{* *}$ & $150.37^{* *}$ & $1.7^{*}$ & $0.7^{* *}$ & $0.3^{* *}$ \\
\hline Error & 495 & 207400.8 & 35041.0 & 81.70 & 1.1 & 0.2 & 0.1 \\
\hline
\end{tabular}

$*, * *$ significant and highly significant at $0.5 \%$ and $0.1 \%$ levels of probability, respectively.

\section{The preliminary strain test (trial A).}

\section{1- Seed cotton yield (SCY)}

Table ( 3 ) shows that the strains $H^{5} 118 / 2011$ and $H^{5} 124 / 2011$ cross (G83Rad x Aust.) x G 91, $H^{5} 129 / 2011$ cross [(G 80 x Aust.) x G 83], $H^{5} 150 / 2011$ cross (G 83 Rad $\times$ Kar. $) \times\left[\left(G 83 \times\right.\right.$ G 80) $\times$ G 89], $H^{6} 198 / 2011$ cross[[(G $83 \times$ G 80) x G 89] x (G83 x Delta Pin)]], $H^{7} 215 / 2011$ cross [(G $83 \times$ G 80) $x$ G89] $x$ Aus, $H^{7} 227 / 2011$ cross (C.B58 x G 90), H²38/2011 cross (Dand.Rad x Kar), $H^{9} 244 / 2011$ cross [G 90 x Pima S62 (24240)], $H^{9} 253 / 2011$ cross [G $91 \times$ Pima S62(24240)], H ${ }^{10} 268 / 2011$ [G $83 \times$ (G $72 \times$ Dand.) x G 91], $\mathrm{H}^{11} 281$ [G83 x (G $72 \times$ Dand.) $\times$ G 83] and Breeder1 of the promising cross [G83 $\times(G 72 \times 5844)] \times G$ 80] recorded significant seed cotton yield (SCY) compared with the check varieties Giza 90 and Giza 80. However, all strains belong to the crosses in Trial A recorded significant seed cotton yield compared with the variety Giza 80 only, except the strains $H^{5} 103 / 2011$ and $H^{5}$ 107/2011 cross [(G 83 $x$ Aus) x G 85], $H^{5} 113 / 2011$ cross [(G 83Rad. x Kar.) x G90] and strain $H^{6} 183 / 2011$ cross [(G $85 \times$ G 83) x G 91] which showed insignificant seed cotton yield compared with Giza 80.

\section{2- Lint cotton yield (LY)}

Table (3) revealed that 17 out of 38 genotypes recorded significant values for lint yield (LY), these strains were $H^{5} 118 / 2011$ and 124/2011cross [(G 83 Rad $x$ Aust.) $x$ G 91], $H^{5} 128 / 2011$ and $H^{5} 129 / 2011$ cross [(G $80 \times$ Aust.) x G 83], $H^{5} 150 / 2011$ cross (G83Rad x Kar.) x [(G 83 x G 80) x G 89], $H^{6} 198 / 2011$ cross [[(G $83 \times$ G 80) x G 89] x (G83 x Delta pine)]], $H^{7} 215 / 2011$ cross [[(G83 x G80) x G89] x Aust.]], $\mathrm{H}^{7} 219 / 2011$ and 222/2011 cross (C.B58 x G90), H ${ }^{8} 238 / 2011$ cross (Dand. Rad. X Kar.), $H^{9} 244 / 2011$ cross [G90 $x$ Pima S6 (24240)], $H^{9}$ 253/2011 and 254/2011 cross G91 x Pima S6 (24202), $H^{10} 268 / 2011$ cross [(G $83 \times$ G 72) x Dand.) x G 91], $H^{11} 281 / 2011$ [( $83 \times$ x $72 \times$ Dand) $\times$ G 85], Breeder 1 of the promising cross [ $83 \times$ ( $75 \times$ 5844) $\times$ G 80] and Breeder 2 of the promising cross ( $G 90 \times$ Aust.). On the other hand G80 had the lowest lint cotton yield compared with all strains in Trial A. 


\section{3- Boll weight (B.W).}

Table (3) showed that the strains $H^{5} 109 / 2011$ and 113/2011cross [(G83Rad. x Kar.) x G90], $H^{5} 118 / 2011$ and $H^{5} 122 / 2011$ cross [(G83Rad x Aust) $x$ G91], $H^{6} 166 / 2011$ cross (G83Rad. $x$ G91) $H^{6} 189 / 2011$ cross [(G83 x G80)xG75 $\times$ G90], $H^{6} 197 / 2011$ and $H^{6} 198 / 2011$ cross [(G83 x G80) x G89] x (G83 x Delta pine), $\mathrm{H}^{7} 215 / 2011$ [(G83 x G80) x G89] x Aust.], $H^{7} 219 / 2011$ and $H^{7} 222 / 2011$ cross (C.B58 $\times$ G 90), ( $H^{7} 227 / 2011$ and $H^{7} 228 / 2011$ cross [(G $80 \times$ Pima S6) $x$ G 91], $H^{8} 238 / 2011$ cross (Dand Rad. x Kar.) and Breeder 2 of the promising cross (G90 x Aust.) didn't exceeded the check varieties G90 and G80 for boll weight. On the other hand, all other strains recorded insignificant mean performance in for boll weight compared with the check varieties Giza 90 and Giza 80.

\section{4- Lint percentage ( $\mathrm{L} \%$ ).}

As shown in Table (3) mean performance for ( $L$ \%) ranged from $36.7 \%$ to $39.2 \%$ for the strain $\mathrm{H}^{7} 222 / 2011$ that was descending from the cross (C.B58 x G90) and $H^{6} 183 / 2011$ derived from the cross [(G $85 \times$ G 83) x G 91], respectively. On the other hand, the strains $H^{5} 109 / 2011$ cross [(G83Rad. $x$ Kar.) $x$ G90], $H^{6} 160 / 2011$ cross (G $83 \mathrm{Rad} \times$ G 91), $H^{6} 189 / 2011$ cross [(G $83 \times$ G 80) x G 75 x G 90], H²22/2011 cross (C.B58 x G 90) and $H^{10} 268 / 2011$ cross [( $83 \times$ G 72) $\times$ Dand.) $\times$ G 91] showed lint percentage values lowest than the check variety Giza 80 while exceeded slightly Giza 90 variety.

\section{5- Seed index (SI).}

It appeared from Table (3) that means of genotypes ranged from 8.5 to 11.4 grams for the strain $H^{6} 188 / 2011$ cross $[((G 83 \times G$ 80) $\times$ G75)) $\times$ G90] and the strain $H^{5} 109 / 2011$ descending from the cross [(G83Rad. $x$ Kar.) $x$ G90]. Three strains $H^{5} 113 / 2011, H^{5} 118 / 2011, H^{5} 122 / 2011, H^{9} 235 / 2011$ and $H^{11} 281 / 2011$ belonged to the crosses [(G83Rad. x Kar.) x G90], [(G83Rad x Aust.) x G91], [G91 x Pima S6 (24202)] and [(G $83 \times$ G 72) $\times$ Dand.) $\times$ G 85] gaves the higher seed index compared with the check varieties Giza 90 and Giza 80, respectively. While insignificant only for the strain $H^{5} 113 / 2011$ of the cross (G 83 Rad. x Kar.) x G 90 which recorded significant and highly significant seed index (SI) compared with Giza 90 and Giza 80.

\section{6- Lint Index (LI).}

Table (3) shows mean of lint index (LI) ranged from 5.3 grams for $H^{6} 109 / 2011$ to 7.7 grams for $H^{6} 188 / 2011$. Seven strains produced significantly higher lint index than the check variety Giza 90, the strains were $H^{5} 113 / 2011$ cross (G83Rad. x Kar.) x G 90, $H^{5} 118 / 2011$ and $H^{5} 122 / 2011$ cross [(G83Rad. x Aust.) x G 91], $H^{5} 130 / 2011$ [(G 80 x Aust.) x G 83], $H^{6} 183 / 2011$ and $H^{6} 184 / 2011$ [(G $85 \times$ G 83) x G 91] and $H^{9} 244 / 2011$ cross $G 90 \times$ Pima $S 6$ (24240). On the other hand three strains 
recorded significant higher lint index (LI) than the another check variety Giza80, the strains were $H^{5} 118 / 2011, H^{5} 130 / 2011$ and $H^{6} 184 / 2011$ belonged to the crosses [( 83 Rad. x Aust.) x G 91], [(G 80 x Aust.) x G 83] and [(G 85 x G 83) x G 91], respectively.

\section{Fiber properties.}

\section{1- Fiber fineness and maturity (Mic).}

Fiber fineness and Maturity (Mic) reading presented in Table (4) showed that the breeder seed of the cross ( $\mathrm{G} 90 \times$ Aust) had 4.8 micronaire reading exceeded all genotypes and check varieties for these trait. Other genotypes in trial A showed micronaire values ranged from 3.7 to 4.4 , while check varieties Giza 90 and Giza 80 recorded 4.0 and 4.2 micronaire values, respectively.

\section{2- Length uniformity ratio (LUR).}

It's appeared from Table (4) that means of this trait ranged from $82.3 \%$ to 88. $H^{7} 228 / 2011$ that belonged to the cross [( $(\mathrm{B} 80 \times$ Pima S6) $\times \mathrm{G} 91]$ and the strain $H^{5} 122 / 2011$ descended from the cross [(G 83 Rad. x Aust.) x G 91], the check varieties Giza 90 and Giza 80 recorded length uniformity ratio (LUR) 84.2\% and $85.3 \%$, respectively.

\section{3- Upper half mean length (UHM).}

The genotypes of all crosses could be considered in long staple category (30m.m) (4), 10 genotypes revealed fiber length exceeded the check varieties Giza 90, Giza 80 and other genotypes in Trial $A$. The genotypes were $H^{5} 103 / 2011$ cross [( $83 \times$ Aust.) $x$ G85], $H^{5} 113 / 2011$ cross (G 83 Rad. x Kar.) x G 90, H5150/2011 (G 83 rad x Kar.) x [( $83 \times$ x 80) x G 89], $H^{6} 166 / 2011$ cross (G 83 Rad. $x$ G 91), $H^{6} 189 / 2011$ cross $\{(\mathrm{G} 83 \times \mathrm{G} \mathrm{80}) \times \mathrm{G} 75] \times \mathrm{G} \mathrm{90 \}}, \mathrm{H}^{6} 198 / 2011$ cross [(G $\left.\left.83 \times \mathrm{G} \mathrm{80}\right) \times \mathrm{G} 89\right] \times(\mathrm{G} 83 \times$ Delta pine), $H^{7} 215 / 2011$ [(G $83 \times$ G 80) x G 89] x Aust.], $H^{9} 235 / 2011$ and $H^{10} 254 / 2011$ (G $91 \times$ Pima $S 62$ 24202) and $H^{10} 257 / 2011$ [G 83 x (G $\left.75 \times 5844\right) \times G$ 91]. Other genotypes were slightly longer than the check varieties (Table 4).

\section{4- Yarn strength (Y.St).}

Most strains were nearly of the same strength or slightly stronger than the check variety Giza 80, while Giza 90 check variety recorded lowest Yarn strength (Y.St) value compared with the genotypes in trial A (Table 4 ).

\section{The advanced strain test (Trial B).}

The advanced strains which selected from Trial A are testing in Trial B, they carried out at five locations in Middle and Upper Egypt i,e. El-Fayoum, Seds, El-Minia, Assuit and Sohaag in order to study the breeding behavior of the genotypes grown under different environments to evaluate the genotype stabilities in different locations. 


\section{A- Yield components}

\section{1- Seed cotton yield (SCY).}

From (Table 5), all genotypes in Trial B exceeded the check variety Giza80 in seed cotton yield. On the other hand seven genotypes out of eighteen genotypes exceeded insignificantly Giza 90 in seed cotton yield (SCY). These genotypes were $H^{5} 136 / 2010$ descending from the cross [( $\left.\left.G 85 \times \mathrm{G} \mathrm{83}\right) \times \mathrm{G} \mathrm{90}\right], H^{6} 177 / 2010$ for the cross [(G $83 \times$ G 80) x G 89] x Aust., $H^{6} 182 / 2010$ belong to the cross C.B58 $\times$ G90, $H^{8} 249 / 2010$ descending from the cross $G 91 \times$ Pima $S 62$ (24202), $H^{9} 262 / 2011$ belong to cross [G $83 \times(\mathrm{G} 75 \times 5844) \times \mathrm{G} 91$ ], $\mathrm{H}^{10} 274 / 2011$ [(G $\left.83 \times \mathrm{G} 72\right) \times$ Dend.] x G85 and breeder2 for the promising cross ( $\mathrm{G} 90 \times$ Aust.).

\section{2- Lint yield (LY).}

Results in Table (5) revealed that the means of lint yield (LY) values ranged from 9.4 Ken/Fed for the strain $\mathrm{H}^{6} 212 / 2010$ of the cross (G80 x Pima S6) x G91 and $\mathrm{H}^{7} 229 / 2010$ of the cross (Denda Rad. $x$ Kar.) to $11.2 \mathrm{Ken} / \mathrm{fed}$ for the strain $H^{6} 177 / 2010$ of the cross [(G $83 \times$ G 80) x G 89] x Aus. All genotypes showed significant increase for lint yield (LY) compared with the check variety Giza 80 . While the strain $H^{6} 177 / 2010$ of the cross [( $(83 \times$ G 80) $\times$ G 89] $\times$ Aus revealed significant increases lint yield (LY) compared with Giza 90 variety. On the other hand the strains $H^{5} 136 / 2010$ descending from the cross [(G $85 \times$ G 83) x G 91], $H^{6} 182 / 2010$ belong to the cross C.B58 x G90, $\mathrm{H}^{8} 249 / 2010$ descending from the cross G91 x Pima S62 (24202), $H^{9} 263 / 2011$ belong to cross [G $83 \times(G 75 \times 5844) \times$ G91], $H^{10} 274 / 2010$ of the cross [(G $83 \times \mathrm{G} 72) \times$ Dend.] $\times \mathrm{G} 85$ and breeder2 for the promising cross ( $\mathrm{G} 90 \times$ Aust.) showed slightly increase lint yield but insignificant compared with the check variety Giza 90.

\section{3- Boll weight (BW).}

The data presented in Table (5) revealed that the two genotypes exceeded insignificant Giza90 and Giza80 in boll weight, $\mathrm{H}^{9} 262 / 2011$ belong to cross [G83 x (G $75 \times 5844) \times \mathrm{G} 91$ ] and $\mathrm{H}^{10} 271 / 2011$ of the cross [(G $\left.83 \times \mathrm{G} 72\right) \times$ Dend.] $\times$ G 85. Other genotypes were less or equal to the check varieties Giza 90 and Giza 80 for boll weight.

\section{3- Lint percentage ( $\mathrm{L} \%$ ).}

Regarding lint percentage value (Table 5), the means of this trait ranged from $38.6 \%$ for the strain $\mathrm{H}^{8} 249 / 2010$ descending from the cross $\mathrm{G} 91 \times$ Pima S62 (24202) to $39.9 \% H^{5} 136 / 2010$ descending from the cross [( $G 85 \times G$ 83) $\times G$ 91]. Five genotypes i.e $H^{5} 136 / 2010, H^{5} 166 / 2010, H^{6} 177 / 2010, H^{10} 274 / 2010$ and breeder2

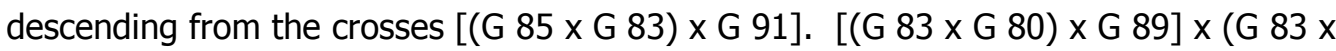
Deltapine), [(G $83 \times$ G 80) x G 89] x Aust, [(G $83 \times$ G 72) x Dend] x G 85 and G 90 x 
Aust gave significantly higher lint percentage ( $\mathrm{L} \%)$ than the check varieties Giza 90 and Giza 80 , respectively.

\section{5- Seed index (SI).}

The results of seed index (SI) in all genotypes under study (Table 5) ranged from $10.0 \mathrm{gm}$ to $12.9 \mathrm{gm}$. The highest seed index $(12.9 \mathrm{gm})$ was recorded for strain $H^{6} 212 / 2010$ of the cross (G $80 \times$ Pima S6) x G91 followed by the check variety Giza 90 and $\mathrm{H}^{10} 271 / 2010$ [(G $\left.83 \times \mathrm{G} 72\right) \times$ Dend.] x G91. Five genotypes recorded seed index (10.6gm) equal to Giza 80 , i.e $H^{5} 112 / 2010$ and 126/2010 of the cross G83Rad. $x$ G91, $H^{8} 234 / 2010$ of the cross $G 91 \times$ Pima $S 62$ (24240), $H^{10} 271 / 2010$ [(G $83 \times$ G 72) $x$ Dend.] x G 85, and breeder1 of the promising cross [G $83 \times(G 75 \times 5844) \times G$ 80], while the other genotypes recorded lowest seed index (SI) than the check varieties Giza 90 and Giza 80.

\section{6- Lint index (LI).}

As shown in Table (5) means of lint index ranged from 6.3gm for the strain $H^{5} 132 / 2010$ of the [ ( $83 \times$ G 80) x G 75)) $x$ Kar] to $8.4 \mathrm{gm}$ for the strain ( $80 \times$ Pima S6) $x$ G91. Seven strains had significantly higher lint index (LI) than the check variety Giza 90 , the strains were $H^{5} 112 / 2010$ and $126 / 2010$ belonging to the cross G83Rad. x G91, $H^{5} 136 / 2010$ belong to the cross (G $85 \times$ G 83) x G 91, $H^{6} 212 / 2010$ descending from the cross ( $\mathrm{G} 80 \times$ Pima S6) $\times \mathrm{G} 91, \mathrm{H}^{8} 234 / 2010$ of the cross $\mathrm{G} 90 \times$ Pima S62 (24240), $\mathrm{H}^{10} 274 / 2010$ of the cross [(G $\left.83 \times \mathrm{G} 72\right) \times$ Dand.) $x \mathrm{G}$ 85] and breeder 1 of the promising cross [G $83 \times(\mathrm{G} 75 \times 5844) \times \mathrm{G} 80$ ].

\section{Fiber properties.}

\section{1- Fiber fineness and Maturity (Mic).}

Fiber fineness and maturity (Mic) reading presented in Table (6) showed that the micrnaire reading (Mic) for all genotypes ranged from 4.0 to 4.3 . the genotypes $H^{5} 136 / 2010$ belong to the cross ( $85 \times$ G 83) x G91 and breeder2 of the promising cross $\mathrm{G} 90 \times$ x Aus had higher micrnaire reading (Mic) than the check varieties Giza 90 and Giza 80. On the other hand the remaining genotypes in Trial B recorded higher micrnaire reading (Mic) than the commercial variety Giza 90 except for the strain $H^{5} 156 / 2010$ belong to the cross [(G $83 \times$ G 80) x G 89] x (G $83 \times$ Delta pine) which had the same micrnaire reading (Mic) as Giza 90.

\section{2- Length uniformity ratio (LUR).}

Length uniformity ratio estimates (Table 6) showed nearly the same trend as the check varieties Giza 90 and Giza 80.

\section{3- Upper half mean length (UHM).}

All genotypes of all crosses could be considered in long staple category (Table 6). All strains didn't exceed the check variety Giza 80 for Upper half mean length 
(UHM) trait, while it were higher in UHM compared with the check variety Giza 90 except the breeder2 of the promising cross (G $90 \times$ Aust) which had lowest UHM compared with Giza 90 and all strains in Trial B.

\section{4- Yarn strength (Y.St).}

Table (6) showed that the genotypes of the crosses G83Rad x G91, [( $683 \times$ G 80) x Giza 75] x Kar, [(G $83 \times$ G 80) x G 75] x G 90, [(G $83 \times$ G 80) x G 89] x (G 83 x Delta pine), (Dand Red. x Kar), G 90 x Pima S62 (24240), [G $83 \times($ G $75 \times 5844) \times$ G 91]. [G83 x (G $72 \times$ Dand.) $\times$ G 91] and [(G $83 \times$ G 72) x Dand.) $\times$ G85], have higher fiber yarn strength than the commercial variety Giza 90 , on the other hand all crosses in Trial B didn't exceed Giza 90 in Yarn strength (Y.St) trait.

\section{Heritability estimates in broad sense ( $h_{\text {.b.s }} \%$ ) and Genetic coefficient of variability (G.C.V \%).}

Table (7) showed heritability estimates in broad sense ( $\mathrm{h}_{\text {.b.s }} \%$ ) and Genetic coefficient of variability (G.C.V) for yield components traits in Trials A and B. High heritability estimates in broad sense ( $h$.b.s $\%$ ) were computed for all yield traits in Trial $A$, indicated that the environment slightly influence in these traits. Broad sense heritability estimates ( $h$. b.s $\%$ ) for yield traits in Trial B were low for seed cotton yield $(\mathrm{SCY})$, lint yield (LY) and boll weight (BW), indicated that the environmental factors had ore effect on these traits. On the other hand, lint percentage $(L \%)$, seed index (SI) and lint index (LI) recorded high heritability estimates in broad sense ( $h_{\text {.b.s }} \%$ ) (more than 50\%), indicating that environment had considerable effect on these traits. The genetic coefficient of variability (G.C.V \%) is important in plant breeding because it helps in the assessment of the range of genetic variability in traits, this parameter helps in comparing variance of various traits. The G.C.V \% values ranged from $2.54 \%$ for lint index (LI) to $61.65 \%$ for lint yield (LY) in Trial A and ranged from $3.98 \%$ for lint percentage $(L \%)$ to $50.0 \%$ for lint yield $(L Y)$ in Trial $B$ Table 7. These values indicated that the environmental effects on all studied traits were considerable. 
Table 3. Means performance of yield components for the strains and cultivated varieties grown in Trial (A) at Seds in 2012 season.

\begin{tabular}{|c|c|c|c|c|c|c|c|c|c|}
\hline $\mathrm{N} . \mathrm{O}$ & Strain & Parent & Origin & $\begin{array}{c}\text { SCY } \\
\text { Can/fed }\end{array}$ & $\begin{array}{l}\text { LCY } \\
\text { Can/fed }\end{array}$ & BW & L\% & SI & LI \\
\hline 1 & $H^{5} 103 / 2011$ & $\mathrm{H}^{4} 67 / 2010$ & $\begin{array}{c}\text { (G83 X } \\
\text { Aust.) X G85 }\end{array}$ & 5.62 & 6.66 & 154 & 37.6 & 10.6 & 6.3 \\
\hline 2 & $\mathrm{H}^{5} 107 / 2011$ & $\mathrm{H}^{4} 68 / 2010$ & "'" "'"' & 5.43 & 6.41 & 154 & 37.5 & 10.2 & 6.1 \\
\hline 3 & $\mathrm{H}^{5} 109 / 2011$ & $\mathrm{H}^{4} 71 / 2010$ & $\begin{array}{l}\text { (G83 Rad. X } \\
\text { Kar.) X G90 }\end{array}$ & 7.07 & 8.27 & 143 & 37.1 & 9.9 & 6.2 \\
\hline 4 & $\mathrm{H}^{5} 113 / 2011$ & $\mathrm{H}^{4} 73 / 2010$ & "'"' "'"' & 6.49 & 7.69 & 149 & 37.6 & 11.4 & 6.8 \\
\hline 5 & $H^{5} 118 / 2011$ & $H^{4} 82 / 2010$ & $\begin{array}{l}\text { (G83 Rad. X } \\
\text { Aust.) X } \\
\text { G91 }\end{array}$ & 8.19 & 9.81 & 144 & 38.0 & 11.0 & 6.9 \\
\hline 6 & $\mathrm{H}^{5} 122 / 2011$ & $\mathrm{H}^{4} 84 / 2010$ & ("'"' "'"' & 7.18 & 8.66 & 148 & 38.3 & 10.9 & 6.8 \\
\hline 7 & $\mathrm{H}^{5} 124 / 2011$ & "'"' "'"' & "'"' "'"' & 8.43 & 10.11 & 158 & 38.1 & 9.2 & 6.3 \\
\hline 8 & $\mathrm{H}^{5} 128 / 2011$ & $\mathrm{H}^{4} 94 / 2010$ & $\begin{array}{c}\text { (G80X } \\
\text { Aust.) X G83 }\end{array}$ & 7.79 & 9.28 & 150 & 37.8 & 10.1 & 6.5 \\
\hline 9 & $H^{5} 129 / 2011$ & "'"' "'"' & "'"' "'"' & 7.98 & 9.45 & 154 & 37.6 & 10.1 & 6.5 \\
\hline 10 & $\mathrm{H}^{5} 130 / 2011$ & $\mathrm{H}^{4} 95 / 2010$ & "'"' "'"' & 7.09 & 8.56 & 159 & 38.3 & 10.7 & 7.2 \\
\hline 11 & $H^{5} 138 / 2011$ & $\mathrm{H}^{4} 104 / 2010$ & $\begin{array}{c}\text { (G83 RadX } \\
\text { Kar.)X } \\
\text { [(G83XG80) } \\
\text { XG89] }\end{array}$ & 7.07 & 8.62 & 156 & 38.7 & 9.7 & 6.0 \\
\hline 12 & $\mathrm{H}^{5} 141 / 2011$ & "'"' " "'"' & "'"' "'"' & 6.49 & 7.79 & 161 & 38.1 & 10.0 & 6.4 \\
\hline 13 & $H^{5} 150 / 2011$ & $\mathrm{H}^{4} 110 / 2010$ & "'"' "'"' & 8.02 & 9.68 & 158 & 38.3 & 9.7 & 6.0 \\
\hline 14 & $\mathrm{H}^{5} 151 / 2011$ & "'"' "'"' & "'"' "'"' & 7.54 & 8.96 & 155 & 37.7 & 10.0 & 6.4 \\
\hline 15 & $H^{6} 160 / 2011$ & $\mathrm{H}^{5} 122 / 2010$ & $\begin{array}{l}\text { G83 Rad X } \\
\text { G91 }\end{array}$ & 7.25 & 8.50 & 158 & 37.2 & 10.6 & 6.4 \\
\hline 16 & $\mathrm{H}^{6} 166 / 2011$ & $\mathrm{H}^{5} 126 / 2010$ & "'"' "'"' & 7.19 & 8.43 & 152 & 37.3 & 10.3 & 6.4 \\
\hline 17 & $H^{6} 176 / 2011$ & $H^{5} 132 / 2010$ & $\begin{array}{c}\text { [G83XG80) } \\
\text { XG75] X } \\
\text { Kar. }\end{array}$ & 7.03 & 8.48 & 158 & 38.3 & 9.9 & 6.1 \\
\hline 18 & $H^{6} 183 / 2011$ & $H^{5} 136 / 2010$ & $\begin{array}{c}\text { (G85XG83) } \\
\text { X G91 }\end{array}$ & 5.95 & 7.36 & 160 & 39.2 & 10.4 & 6.6 \\
\hline 19 & $\mathrm{H}^{6} 184 / 2011$ & "'"' "'"' & "'"' "'"' & 6.93 & 8.27 & 159 & 37.9 & 11.1 & 7.7 \\
\hline 20 & $H^{6} 188 / 2011$ & $H^{5} 152 / 2010$ & $\begin{array}{c}\text { [G83XG80) } \\
\text { XG75] X } \\
\text { G90 }\end{array}$ & 7.44 & 8.78 & 158 & 37.4 & 8.5 & 5.3 \\
\hline 21 & $\mathrm{H}^{6} 189 / 2011$ & "'"' "'"' & "I"' "'"' & 7.64 & 8.96 & 152 & 37.2 & 9.5 & 5.7 \\
\hline 22 & $H^{6} 197 / 2011$ & $\mathrm{H}^{5} 156 / 2010$ & $\begin{array}{c}\text { (G83XG80) } \\
\text { XG891X } \\
\text { (G83X } \\
\text { Deltapin) } \\
\end{array}$ & 7.53 & 8.98 & 151 & 37.9 & 9.7 & 6.4 \\
\hline 23 & $H^{6} 198 / 2011$ & "'"' " "'"' & "'"' "'"' & 8.69 & 10.37 & 142 & 37.9 & 10.3 & 6.0 \\
\hline 24 & $H^{6} 213 / 2011$ & $\mathrm{H}^{5} 166 / 2010$ & "'"' "'"' & 6.69 & 8.03 & 162 & 38.1 & 9.89 & 6.4 \\
\hline 25 & $H^{7} 215 / 2011$ & $H^{6} 177 / 2010$ & $\begin{array}{c}\text { [(G83XG80) } \\
\text { XG89] X } \\
\text { Aust. }\end{array}$ & 9.37 & 11.34 & 144 & 38.4 & 9.9 & 6.3 \\
\hline 26 & $H^{7} 219 / 2011$ & $\mathrm{H}^{6} 182 / 2010$ & $\begin{array}{c}\text { C.B58 } \\
\text { G90 }\end{array}$ & 7.63 & 9.02 & 145 & 37.5 & 9.6 & 6.5 \\
\hline 27 & $\mathrm{H}^{7} 222 / 2011$ & "'"' "'"' & "'"' "'"' & 8.02 & 9.26 & 147 & 36.7 & 10.6 & 6.0 \\
\hline 28 & $\mathrm{H}^{7} 227 / 2011$ & $\mathrm{H}^{6} 212 / 2010$ & $\begin{array}{l}\text { (G80 X Pima } \\
\text { S6) X G91 }\end{array}$ & 7.41 & 8.73 & 152 & 37.4 & 9.8 & 6.3 \\
\hline 29 & $\mathrm{H}^{\prime} 228 / 2011$ & "'"' "'"' & "'"' "'"' & 7.37 & 8.72 & 144 & 37.6 & 9.3 & 5.9 \\
\hline 30 & $\mathrm{H}^{8} 238 / 2011$ & $\mathrm{H}^{7} 229 / 2010$ & $\begin{array}{c}\text { Dand Rad. X } \\
\text { KAR. }\end{array}$ & 7.91 & 9.50 & 140 & 38.1 & 9.5 & 6.0 \\
\hline 31 & $\mathrm{H}^{9} 244 / 2011$ & $\mathrm{H}^{8} 234 / 2010$ & $\begin{array}{l}\text { G90 X Pima } \\
\text { S62 (24240) }\end{array}$ & 8.14 & 9.79 & 155 & 38.2 & 10.6 & 6.0 \\
\hline 32 & $\mathrm{H}^{9} 253 / 2011$ & $\mathrm{H}^{8} 249 / 2010$ & $\begin{array}{l}\text { G91 X Pimá } \\
\text { S62 (24202) }\end{array}$ & 8.28 & 9.94 & 157 & 38.1 & 11.2 & 6.7 \\
\hline 33 & $\mathrm{H}^{9} 254 / 2011$ & "'"' "'"' & "'"' "'"' & 8.14 & 9.73 & 158 & 37.9 & 10.3 & 6.1 \\
\hline 34 & $\mathrm{H}^{10} 257 / 2011$ & $H^{9} 262 / 2010$ & $\begin{array}{c}{[\mathrm{G} 83 \times(\mathrm{G} 75} \\
\times 5844)] \times \\
\mathrm{G91}\end{array}$ & 7.09 & 8.57 & 161 & 38.3 & 10.1 & 6.5 \\
\hline 35 & $\mathrm{H}^{10} 268 / 2011$ & $H^{9} 271 / 2010$ & $\begin{array}{c}{[(G .83} \\
\text { xG.72) } X \\
\text { Dand] } X \\
\text { G91 }\end{array}$ & 8.40 & 9.86 & 160 & 37.3 & 10.4 & 6.0 \\
\hline 36 & $\mathrm{H}^{11} 281 / 2011$ & $\mathrm{H}^{10} 274 / 2010$ & $\begin{array}{c}\text { LG.83 } \\
\text { xG.72) } \\
\text { Dand } x \\
\text { G85 } \\
\end{array}$ & 7.76 & 9.28 & 158 & 38.0 & 10.8 & 6.0 \\
\hline 37 & \multicolumn{2}{|c|}{ Breeder1 } & $\begin{array}{r}G 83 X(G 75 \\
\times 5844) \times \\
\text { G80 }\end{array}$ & 9.90 & 11.88 & 161 & 38.1 & 10.2 & 6.3 \\
\hline 38 & \multicolumn{2}{|c|}{ Breeder2 } & $\begin{array}{l}\text { (G90X } \\
\text { Aust.) }\end{array}$ & 7.73 & 9.48 & 143 & 38.9 & 9.0 & 6.0 \\
\hline 39 & \multicolumn{2}{|c|}{ Giza 90} & $\begin{array}{l}\text { (G.83X } \\
\text { Dand) }\end{array}$ & 5.92 & 6.82 & 155 & 36.6 & 10.7 & 6.4 \\
\hline \multirow[t]{4}{*}{40} & \multicolumn{2}{|c|}{ GIza 80} & $\begin{array}{c}(\mathrm{G} .66 \mathrm{X} \\
\mathrm{G} .73)\end{array}$ & 4.70 & 5.52 & 154 & 37.3 & 10.5 & 6.7 \\
\hline & \multicolumn{3}{|c|}{ Mean } & 7.41 & 8.84 & 153 & 38.4 & 10.2 & 6.4 \\
\hline & \multicolumn{3}{|c|}{ LSD5\% } & 1.94 & 2.42 & 8.0 & 0.527 & $\begin{array}{c}0.21 \\
6\end{array}$ & 0.169 \\
\hline & \multicolumn{3}{|c|}{ LSD.1\% } & N.S & N.S & 9.0 & 0.692 & 0.28 & 0.222 \\
\hline
\end{tabular}


Table 4 . Means performance for fiber properties of the strains and cultivated varieties grown in Trial (A) at Seds in 2012 season.

\begin{tabular}{|c|c|c|c|c|c|c|c|}
\hline N.O & Strain & Parent & Origin & Mic & LUR & UHM & Y.St \\
\hline 1 & $H^{5} 103 / 2011$ & $\mathrm{H}^{4} 67 / 2010$ & (G83 X Aust.) X G85 & 4 & 85.9 & 31.5 & 2255 \\
\hline 2 & $\mathrm{H}^{5} 107 / 2011$ & $\mathrm{H}^{4} 68 / 2010$ & "'" "'"' & 4 & 86.0 & 30.4 & 2190 \\
\hline 3 & $H^{5} 109 / 2011$ & $\mathrm{H}^{4} 71 / 2010$ & (G83 Rad. X Kar.) X G90 & 3.9 & 84.5 & 30 & 2240 \\
\hline 4 & $H^{5} 113 / 2011$ & $\mathrm{H}^{4} 73 / 2010$ & "'" "'"' & 3.9 & 84.0 & 31.3 & 2175 \\
\hline 5 & $H^{5} 118 / 2011$ & $\mathrm{H}^{4} 82 / 2010$ & (G83 Rad. X Aust.) X G91 & 4.2 & 83.5 & 30.8 & 2110 \\
\hline 6 & $\mathrm{H}^{5} 122 / 2011$ & $\mathrm{H}^{4} 84 / 2010$ & "'" "'"' & 4 & 88.0 & 29.5 & 2150 \\
\hline 7 & $H^{5} 124 / 2011$ & "'"' "'"' & "'"' "'"' & 4.1 & 83.0 & 29.7 & 2175 \\
\hline 8 & $\mathrm{H}^{5} 128 / 2011$ & H $494 / 2010$ & (G80 X Aust.) X G83 & 4 & 85.7 & 30.8 & 2330 \\
\hline 9 & $\mathrm{H}^{5} 129 / 2011$ & "'"' "'"' & "'"' "'"' & 4.1 & 80.0 & 29.6 & 2000 \\
\hline 10 & $\mathrm{H}^{5} 130 / 2011$ & $\mathrm{H}^{4} 95 / 2010$ & "'" "'"' & 4.2 & 85.3 & 30.5 & 2160 \\
\hline 11 & $H^{5} 138 / 2011$ & $H^{4} 104 / 2010$ & $\begin{array}{l}(\text { G83 Rad X Kar.) X } \\
\text { [(G83XG80)XG89] }\end{array}$ & 4.1 & 83.0 & 29.8 & 2015 \\
\hline 12 & $H^{5} 141 / 2011$ & "'"' "'"' & "'"' "'"' & 4.2 & 84.5 & 29.3 & 2130 \\
\hline 13 & $H^{5} 150 / 2011$ & $\mathrm{H}^{4} 110 / 2010$ & "'"' "'"' & 3.9 & 85.8 & 31 & 2100 \\
\hline 14 & $H^{5} 151 / 2011$ & "'"' "'"' & "'"' "'"' & 4 & 82.7 & 29.6 & 2105 \\
\hline 15 & $H^{6} 160 / 2011$ & $\mathrm{H}^{5} 122 / 2010$ & G83 Rad X G91 & 3.8 & 84.2 & 31.1 & 2175 \\
\hline 16 & $\mathrm{H}^{6} 166 / 2011$ & $\mathrm{H}^{5} 126 / 2010$ & "'"' "'"' & 3.9 & 86.1 & 30.7 & 2130 \\
\hline 17 & $\mathrm{H}^{6} 176 / 2011$ & $\mathrm{H}^{5} 132 / 2010$ & [(G83XG80)XG75] X Kar. & 4.1 & 84.6 & 29.7 & 2150 \\
\hline 18 & $H^{6} 183 / 2011$ & $H^{5} 136 / 2010$ & (G85XG83) X G91 & 4.1 & 83.6 & 30.2 & 2015 \\
\hline 19 & $H^{6} 184 / 2011$ & "'"' "'"' & "'" "'"' & 4.3 & 84.2 & 29.6 & 2090 \\
\hline 20 & $H^{6} 188 / 2011$ & $\mathrm{H}^{5} 152 / 2010$ & [(G83XG80)XG75]X G90 & 3.8 & 84.4 & 30.1 & 2200 \\
\hline 21 & $H^{6} 189 / 2011$ & "'" "'m & "'"' "'"' & 3.8 & 84.1 & 31.4 & 2115 \\
\hline 22 & $H^{6} 197 / 2011$ & $\mathrm{H}^{5} 156 / 2010$ & [(G83XG80)XG89] X (G83X Deltapin) & 3.8 & 84.4 & 29.8 & 2010 \\
\hline 23 & $H^{6} 198 / 2011$ & "'" " "'"' & "'" "'"' & 4 & 83.3 & 31.3 & 2350 \\
\hline 24 & $H^{6} 213 / 2011$ & $\mathrm{H}^{5} 166 / 2010$ & "'" "'"' & 4 & 84.8 & 29.8 & 2085 \\
\hline 25 & $\mathrm{H}^{7} 215 / 2011$ & $\mathrm{H}^{6} 177 / 2010$ & [(G83XG80)XG89] X Aust. & 3.8 & 85.7 & 31.2 & 2410 \\
\hline 26 & $\mathrm{H}^{7} 219 / 2011$ & $H^{6} 182 / 2010$ & C.B $58 \times$ G90 & 3.8 & 85.8 & 29.9 & 2110 \\
\hline 27 & $\mathrm{H}^{7} 222 / 2011$ & "'"' "'"' & "'" "'"' & 4 & 85.3 & 30.2 & 2010 \\
\hline 28 & $\mathrm{H}^{7} 227 / 2011$ & $H^{6} 212 / 2010$ & (G80 X Pima S6) X G91 & 3.7 & 85.4 & 29.5 & 2160 \\
\hline 29 & $\mathrm{H}^{7} 228 / 2011$ & "'" "'"' & "'" "'"' & 3.7 & 82.3 & 29.6 & 2105 \\
\hline 30 & $\mathrm{H}^{8} 238 / 2011$ & $\mathrm{H}^{7} 229 / 2010$ & Dand Rad. X KAR. & 4 & 83.6 & 30.4 & 2255 \\
\hline 31 & $\mathrm{H}^{9} 244 / 2011$ & $\mathrm{H}^{8} 234 / 2010$ & G90 X Pima S62 (24240) & 4 & 82.5 & 29.3 & 2135 \\
\hline 32 & $\mathrm{H}^{9} 253 / 2011$ & $\mathrm{H}^{8} 249 / 2010$ & G91 X Pima S62 (24202) & 4.1 & 85.0 & 32.1 & 2445 \\
\hline 33 & $\mathrm{H}^{9} 254 / 2011$ & "'"' "'"' & "'" "'"' & 4.3 & 85.0 & 31.2 & 2125 \\
\hline 34 & $\mathrm{H}^{10} 257 / 2011$ & $\mathrm{H}^{9} 262 / 2010$ & {$[\mathrm{G} 83 \mathrm{X}(\mathrm{G} 75 \times \mathrm{X} 5844)] \times \mathrm{G} 91$} & 4.4 & 85.3 & 31.5 & 2375 \\
\hline 35 & $\mathrm{H}^{10} 268 / 2011$ & $\mathrm{H}^{9} 271 / 2010$ & [(G.83 xG.72) X Dand] X G91 & 4.3 & 83.8 & 29.3 & 2130 \\
\hline 36 & $\mathrm{H}^{11} 281 / 2011$ & $\mathrm{H}^{10} 274 / 2010$ & [(G.83 XG.72) X Dand] X G85 & 4.2 & 83.3 & 30.4 & 2070 \\
\hline 37 & \multicolumn{2}{|c|}{ Breeder1 } & [G83X (G75 X 5844) X G80] & 4.4 & 85.4 & 29.5 & 2010 \\
\hline 38 & \multicolumn{2}{|c|}{ Breeder2 } & (G90 X Aust.) & 4.8 & 84.8 & 30.3 & 2100 \\
\hline 39 & \multicolumn{2}{|c|}{ Giza 90} & (G.83 x Dand $)$ & 4.0 & 84.2 & 29.2 & 1990 \\
\hline 40 & \multicolumn{2}{|c|}{ GIza 80} & $(G .66 \times$ G.73) & 4.2 & 85.3 & 30.2 & 2200 \\
\hline & \multicolumn{3}{|c|}{ Mean } & & & & \\
\hline
\end{tabular}


Table 5. Combined analysis for yield component of selected strains and cultivated varieties in Trial B at six different locations in Upper Egypt in 2012 season.

\begin{tabular}{|c|c|c|c|c|c|c|c|c|c|}
\hline NO & Strain & Parent & Origin & $\begin{array}{c}\text { SCY } \\
\text { Kan \F } \\
\text { ed }\end{array}$ & $\begin{array}{c}\text { LCY } \\
\text { Kan\F } \\
\text { ed }\end{array}$ & BW & L\% & SI & LI \\
\hline 1 & $\begin{array}{c}\mathrm{H}^{5} 112 / 201 \\
0\end{array}$ & $H^{4} 52 / 2009$ & G83 Rad. X G91 & 8.1 & 10.0 & 146 & 39.2 & 10.6 & 6.9 \\
\hline 2 & $\begin{array}{c}\mathrm{H}^{5} 126 / 201 \\
0\end{array}$ & $H^{4} 56 / 2009$ & "'"' "'"' & 8.4 & 10.3 & 147 & 38.9 & 10.6 & 6.9 \\
\hline 3 & $\begin{array}{c}\mathrm{H}^{5} 132 / 201 \\
0\end{array}$ & $\mathrm{H}^{4} 68 / 2009$ & [(G83XG80)XG75] X Kar. & 8.3 & 10.0 & 151 & 38.4 & 10.2 & 6.3 \\
\hline 4 & $\begin{array}{c}\mathrm{H}^{5} 136 / 201 \\
0\end{array}$ & $H^{4} 72 / 2009$ & (G85XG83)XG91 & 8.6 & 10.8 & 146 & 39.9 & 10.4 & 7.0 \\
\hline 5 & $\begin{array}{c}\mathrm{H}^{5} 152 / 201 \\
0 \\
\end{array}$ & $\mathrm{H}^{4} 89 / 2009$ & [(G83XG80)XG75] X G90 & 8.1 & 9.8 & 146 & 38.6 & 10.5 & 6.7 \\
\hline 6 & $\begin{array}{c}\mathrm{H}^{5} 156 / 201 \\
0 \\
\end{array}$ & $\mathrm{H}^{4} 93 / 2009$ & $\begin{array}{r}\text { [(G83XG80)XG89]X(G83X } \\
\text { Delta Pine) }\end{array}$ & 8.5 & 10.6 & 145 & 39.2 & 10.2 & 6.7 \\
\hline 7 & $\begin{array}{c}\mathrm{H}^{5} 166 / 201 \\
0\end{array}$ & $\begin{array}{c}H^{4} \\
101 / 2009\end{array}$ & "'"' "'"' & 7.9 & 9.8 & 146 & 39.3 & 10.5 & 6.8 \\
\hline 8 & $\begin{array}{c}\mathrm{H}^{6} 177 / 201 \\
0 \\
\end{array}$ & $\begin{array}{c}H^{5} \\
112 / 2009 \\
\end{array}$ & [(G83XG80)XG89] X Aust. & 8.6 & 11.2 & 144 & 39.5 & 10.2 & 6.7 \\
\hline 9 & $\begin{array}{c}\mathrm{H}^{6} 182 / 201 \\
0 \\
\end{array}$ & $\begin{array}{c}H^{5} \\
118 / 2009 \\
\end{array}$ & C.B $58 \times$ G90 & 8.7 & 10.6 & 146 & 38.6 & 10.3 & 6.6 \\
\hline 10 & $\begin{array}{c}\mathrm{H}^{6} 212 / 201 \\
0 \\
\end{array}$ & $\begin{array}{c}H^{5} \\
150 / 2009 \\
\end{array}$ & (G80 X Pima S6)X G91 & 7.6 & 9.4 & 147 & 38.9 & 12.9 & 8.4 \\
\hline 11 & $\begin{array}{c}\mathrm{H}^{7} 229 / 201 \\
0 \\
\end{array}$ & $\begin{array}{c}H^{6} \\
186 / 2009 \\
\end{array}$ & Dand Radi. X Kar. & 7.7 & 9.4 & 150 & 39.2 & 10.1 & 6.6 \\
\hline 12 & $\begin{array}{c}\mathrm{H}^{8} 234 / 201 \\
0\end{array}$ & $\begin{array}{c}H^{7} \\
190 / 2009\end{array}$ & G90 X Pima S62 (24240) & 8.1 & 9.9 & 148 & 38.7 & 10.6 & 7.1 \\
\hline 13 & $\begin{array}{c}\mathrm{H}^{8} 249 / 201 \\
0\end{array}$ & $\begin{array}{c}H^{7} \\
216 / 2009 \\
\end{array}$ & G91 X Pima S62 (24202) & 8.8 & 10.6 & 149 & 38.3 & 10.3 & 6.7 \\
\hline 14 & $\begin{array}{c}\mathrm{H}^{9} 262 / 201 \\
0 \\
\end{array}$ & $\begin{array}{c}H^{8} \\
240 / 2009 \\
\end{array}$ & [G83X(G75X5844) ]X G91 & 8.8 & 10.8 & 152 & 38.9 & 10.4 & 6.8 \\
\hline 15 & $\begin{array}{c}\mathrm{H}^{10} 271 / 20 \\
10\end{array}$ & $\begin{array}{c}H^{9} \\
255 / 2009\end{array}$ & [(G83xG72)xDand]X G91 & 8.1 & 9.8 & 152 & 38.2 & 10.7 & 6.7 \\
\hline 16 & $\begin{array}{c}\mathrm{H}^{10} 274 / 20 \\
10 \\
\end{array}$ & $\begin{array}{c}\mathrm{H}^{9} \\
264 / 2009 \\
\end{array}$ & $\begin{array}{c}\text { [(G.83 xG.72) x Dand }] X \\
\text { G85 } \\
\end{array}$ & 8.6 & 10.7 & 149 & 39.3 & 10.6 & 6.9 \\
\hline 17 & & & [G83X (G75 X 5844) X G80] & 8.5 & 10.4 & 147 & 38.8 & 10.6 & 6.9 \\
\hline 18 & & & (G90 X AUS.) & 8.7 & 10.8 & 147 & 39.4 & 10.0 & 6.6 \\
\hline 19 & & & (G.83 x Dand) & 8.5 & 10.2 & 149 & 38.0 & 10.8 & 6.7 \\
\hline 20 & & & (G.66 x G.73) & 6.8 & 8.3 & 151 & 38.8 & 10.6 & 70 \\
\hline \multicolumn{10}{|c|}{ Mean } \\
\hline & & & $5 \%$ & 0.85 & 1.11 & 4.57 & 0.527 & 0.216 & 0.169 \\
\hline & & & & 1.12 & 1.45 & 6.01 & 0.692 & 0.284 & 0.222 \\
\hline
\end{tabular}


Table 6. Combined analysis for yield component of selected strains and cultivated varieties In Trial B at six different locations in Upper Egypt in 2012 season.

\begin{tabular}{|c|c|c|c|c|c|c|c|}
\hline NO & Strain & Parent & Origin & Mic & HW & $2.5 \% \mathrm{SL}$ & Y.St \\
\hline 1 & $\mathrm{H}^{5} 112 / 2010$ & $\mathrm{H}^{4} 52 / 2009$ & G83 Rad. X G91 & 4.1 & 84.6 & 31.5 & 2265 \\
\hline 2 & $\mathrm{H}^{5} 126 / 2010$ & $\mathrm{H}^{4} 56 / 2009$ & 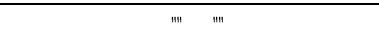 & 4.2 & 84.5 & 31.2 & 2275 \\
\hline 3 & $\mathrm{H}^{5} 132 / 2010$ & $\mathrm{H}^{4} 68 / 2009$ & [(G83XG80)XG75] X Kar. & 4.2 & 85.9 & 31.3 & 2205 \\
\hline 4 & $\mathrm{H}^{5} 136 / 2010$ & $\mathrm{H}^{4} 72 / 2009$ & (G85XG83)XG91 & 4.3 & 84.2 & 29.8 & 2155 \\
\hline 5 & $\mathrm{H}^{5} 152 / 2010$ & $\mathrm{H}^{4} 89 / 2009$ & [(G83XG80)XG75] X G90 & 4.1 & 85.2 & 30.6 & 2220 \\
\hline 6 & $H^{5} 156 / 2010$ & $H^{4} 93 / 2009$ & $\begin{array}{c}\text { [(G83XG80)XG89] X (G83X Delta } \\
\text { Pine) }\end{array}$ & 4.0 & 85.1 & 30.4 & 2200 \\
\hline 7 & $\mathrm{H}^{5} 166 / 2010$ & $H^{4} 101 / 2009$ & "'"' "'" & 4.2 & 85.1 & 30.4 & 2260 \\
\hline 8 & $H^{6} 177 / 2010$ & $\mathrm{H}^{5} 112 / 2009$ & [(G83XG80)XG89] X Aust. & 4.1 & 85.1 & 30.1 & 2155 \\
\hline 9 & $H^{6} 182 / 2010$ & $\mathrm{H}^{5} 118 / 2009$ & C.B 58 X G90 & 4.1 & 83.9 & 30.2 & 2140 \\
\hline 10 & $H^{6} 212 / 2010$ & $\mathrm{H}^{5} 150 / 2009$ & (G80 X Pima S6)X G91 & 4.2 & 83.0 & 29.8 & 2140 \\
\hline 11 & $\mathrm{H}^{7} 229 / 2010$ & $H^{6} 186 / 2009$ & Dand Rad. X KAR. & 4.2 & 85.1 & 30.3 & 2255 \\
\hline 12 & $\mathrm{H}^{8} 234 / 2010$ & $H^{7} \quad 190 / 2009$ & G90 X Pima S62 (24240) & 4.2 & 84.2 & 30.2 & 2235 \\
\hline 13 & $\mathrm{H}^{8} 249 / 2010$ & $H^{7} 216 / 2009$ & G91 X Pima S62 (24202) & 4.2 & 84.4 & 30.2 & 2190 \\
\hline 14 & $\mathrm{H}^{9} 262 / 2010$ & $\mathrm{H}^{8} 240 / 2009$ & [G83X (G75 X 5844) ]X G91 & 4.2 & 85.6 & 30.8 & 2245 \\
\hline 15 & $\mathrm{H}^{10} 271 / 2010$ & $H^{9} 255 / 2009$ & [(G.83 xG.72) x Dand]X G91 & 4.1 & 85.9 & 30.7 & 2278 \\
\hline 16 & $\mathrm{H}^{10} 274 / 2010$ & $H^{9} 264 / 2009$ & [(G.83 xG.72) x Dand]X G85 & 4.1 & 85.2 & 30.0 & 2255 \\
\hline 17 & \multicolumn{2}{|c|}{ Breeder1 } & [G83X (G75 X 5844) X G80] & 4.1 & 84.1 & 30.0 & 2175 \\
\hline 18 & \multicolumn{2}{|c|}{ Breeder2 } & (G90 X Aust.) & 4.3 & 85.2 & 29.5 & 2125 \\
\hline 19 & \multicolumn{2}{|c|}{ Giza 90} & (G.83 x Dand) & 4.0 & 84.8 & 29.8 & 2195 \\
\hline 20 & \multicolumn{2}{|c|}{ Giza 80} & (G.66 x G.73) & 4.2 & 86.9 & 31.6 & 2335 \\
\hline & \multicolumn{3}{|c|}{ Total } & & & & \\
\hline & \multicolumn{3}{|c|}{ Mean } & & & & \\
\hline
\end{tabular}


Table 7. Heritability Stamatas in broad sense $\left(\mathrm{h}_{\text {b.s\% }}\right)$ and genetic coefficient of variability (G.C.V\%) for yield traits in Trials A and B.

\begin{tabular}{|c|c|c|c|c|}
\hline \multirow{2}{*}{ Traits } & \multicolumn{2}{|c|}{ Trial A } & \multicolumn{2}{c|}{ Trial B } \\
\cline { 2 - 5 } & $\mathrm{h}_{\text {.b.s } \%}$ & G.C.V\% & $\mathrm{h}_{\text {b.s. } \%}$ & G.C.V\% \\
\hline SCY & 63.705 & 15.867 & 23.33 & 11.66 \\
\hline LY & 64.913 & 61.646 & 26.18 & 50.041 \\
\hline BW & 72.626 & 36.939 & 14.00 & 18.072 \\
\hline L\% & 62.460 & 4.025 & 52.006 & 3.98 \\
\hline SI & 82.675 & 38.053 & 64.290 & 21.408 \\
\hline LY & 77.930 & 2.543 & 62.111 & 14.433 \\
\hline
\end{tabular}

\section{CONCLUSION}

Results in Trials A and B indicated that the genotypes of the cross [(G83xG80) $x$ G89] $x$ Aust. exceeded all genotypes belonging to the different crosses and the check varieties for seed and lint cotton yield and they had a suitable fiber quality for long staple cotton which grown in Upper Egypt. Therefore, it could be considered as a promising material and to be followed in the breeding program.

Genotypes mean squares in Trial A were highly significant for all yield components traits. While in Trial B Combined mean squares results of the genotypes (G) were highly significant and significant for all yield traits except for lint index (LI). Environments $(E)$ mean squares were highly significant for all studied yield traits. Genotypes-environment interaction ( $\mathrm{G} \times \mathrm{E}$ ) mean squares were highly significant for all yield traits except for lint percentage (L\%) which showed significant combined mean squares, indicating change in performance of genotypes from one location to another. In other words, the rank of a genotype differed from one location to another

The G.C.V \% values ranged from $2.54 \%$ for lint index (LI) to $61.65 \%$ for lint yield ( $L Y$ ) in Trial $A$ and ranged from $3.98 \%$ for lint percentage $(L \%)$ to $50.0 \%$ for lint yield (LY) in Trial B. These values indicated that the environmental effects on all studied traits were considerable.

The promising strains that were selected from Trial A will be grown in Trial B in the next season with the check varieties Giza 90 and Giza 80. It should be noted that Trial A represents the descendant from the progenies of strains grown in Trial B in the same season, besides the strains that reached the fifth generation. 


\section{REFERENCES}

1- A.S.T.M. 1998. American Society for Testing Materials. D 1445-95, vol. 07.Easton, MD, USA.

2- El-Adly, H.H., S.A.S. Mohamed and G.M. Hemaida. 2006. Genetic diversity of some cotton genotypes (Gossypium barbadense L). Egypt. J. Agric. Res., 84(5), 15491559.

3- El-Adly, H.H., and E.A.M.Eissa, 2010. Estimate of genotypic variance and covariance components in some Egyptian cotton genotypes. Egypt. J. of. Appl.Sci.25 (3): 80-90

4- El- Feki T.A., M.G.I. Beheary and A.A.A. El-Akhedar. 2005. Technological and genetical estimates for yield and fiber properties of some extra-long Egyptian cotton promising genotypes. J. Agric. Res. Tanta Univ., 31(1) 32-45.

5- El-Feki, T.A, M.A.A.Nagib, Sayeda S.H.El-Helow and M.A.M. Allam. 2002. The prediction for seed cotton and lint yield in different generations of cross cotton.Minia J.of Agric. Res of Develop.Vol (22) No.4 PP 369-380.

6- El-Ameen, T.M., M.N.A. Nazmey and A.E.M. Eissa. 2004. Genotype and genotypeenvironment components of variation in cotton breading lines of $\mathrm{G}$. barbadense. Minia J. of Agric. Res. \& Develop. Vol (24) No.2 pp 285-296.

7- Le Clerg, E.L., Leonard W.H. and A.G. Clark. 1962. Field Plot Techniques. Burgess Publishing Co.

8- Mohamed S.A.S, H.H. El-Adly and E.A.M.Eissa, 2003. Evaluation of some Egyptian cotton genotypes under different environments. Egypt. J.Agri.Res. 81 (4): 19971816.

9- Mohamed S.A.S, A.A. Mohamed and M.N.A. Nazmy. 2005. Mean performance and stability of some cotton genotypes (G. barbadense $L$ ) under six different locations in Egypt. Minia J. of Agric. Res. \& Develop. Vol (25) No.3 pp 535-550.

10- Nazmy. M.N.A and Zeina. 2005. Genotype- environment interaction and genotypic stability for some long staple cotton genotypes. Egypt. J. of. Appl.Sci.

11- Samia,E.Ali. Eman, M.R.M Saleh and M.S.M.Srour. 2012. Evaluation of some long staple cotton strains under different environments. Egypt. J. plant Breed.16 (1):41-50. 2012.

12- Snedecor, G.W. 1965. Statistical Method. Iowa Stat. Univ. Press, Ames, Iowa U.S.A. 


\section{تقييم بعض الأقطان طويلة التيلة}

\section{المنزرعة فى بيئات مختلفة}

حسن حسين العدلى - حسين صلاح خليفة - صلاح الاين رشاد نصر سعيد

$$
\text { معهد بحوث القطن - مركز البحوث الزراعية }
$$

يهدف هذا البحث الى تقييم بعض سلالات هجن القطن طويل التيلة للوجه القبلى مفارنة بالصنفين التجارين المنزرعين جيزة 90 و جيزة 80 وذللك من خلال تجربة أختبار النسل بتجربة فئ

المحصول الاولية (أ) المقامة بمحطة البحوث الزر اعية بسدس ونجارب المحصول المنقدمة (ب) المبرة المقامة بمحافظات الوجه القبلى: الفيوم - بنى سويف (سدس) - المنيا - أسيوط - سوهاج فى موسم .2012

\section{ويمكن تلخيص أهم النتائج فيما يلى :}

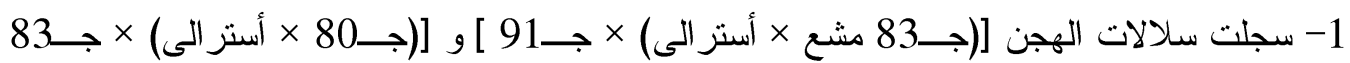

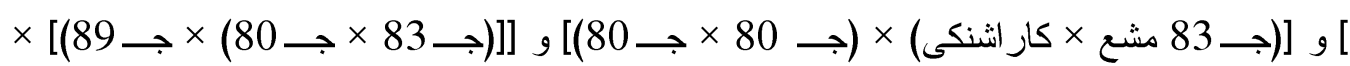

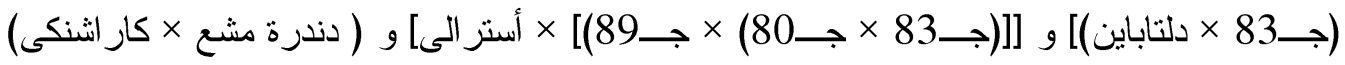

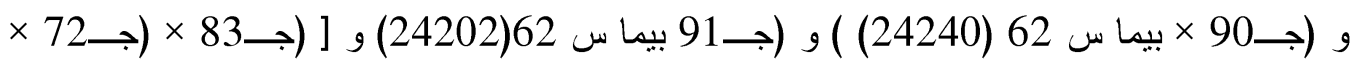

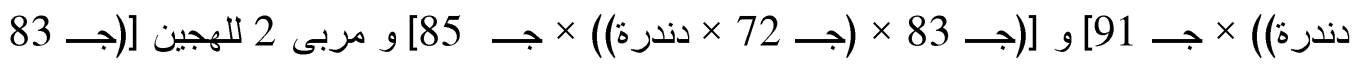

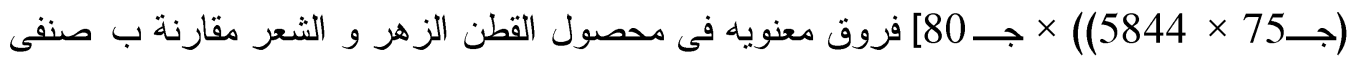
المقارنة جيزة90 و جيزة80 في تجربة المحصول جلألاولية (أ).

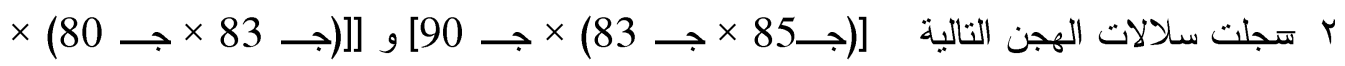

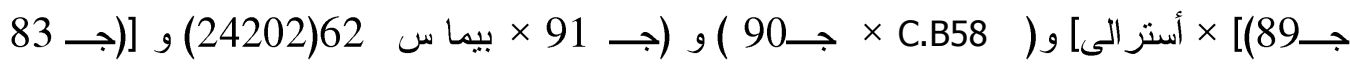

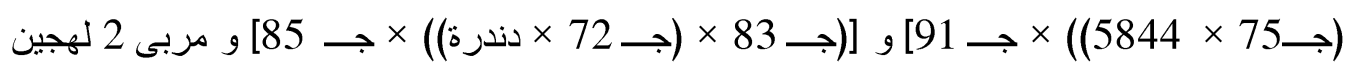
المبشر جـ90 × أستر الى زيادة فى محصول القطن الزهر و الشعر مقارنة بصنفى المقارنة جيزة 90 و جيزة80 فى تجربة المحصول (ب) .

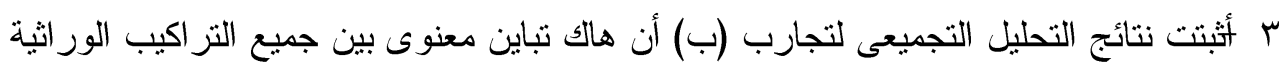

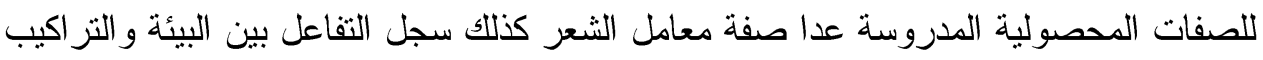
الور اثية تياين عالى المعنوية لكل الصفات المحصولية المدروسة عدا صفة تصافى الحليج حيث كان التفاعل معنوى بين البيئة و التزر اكيب الور اثية. ع سجلت درجة التوريث فى المعنى الواسع قيم عالية للصفات المحصولية المدروسة في تجربة (أ). بينما سجلت درجة التوريث فى المعنى الو اسع للصفات المحصولية المدروسة فى تجربة (ب) قيم 
منخفضة لصفة محصول القطن الزهر و الثشعر ووزن اللوزة اما صفات تصافى الحليج ومعامل البذرة ومعامل الثعر فقد سجلت درجة توريث عالية فى المعنى الواسع.

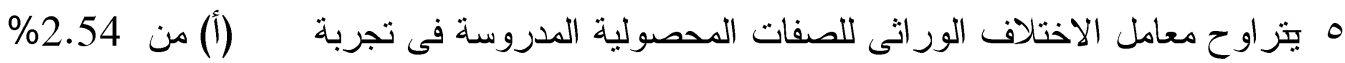

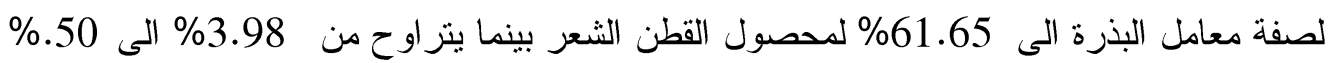
لصفتى تصافى الحليج ومحصول القطن الثعر فى تجربة (ب) على التو الى. التوصيات المستقبلية أظهرت نتائج تجربة المحصول الاوليه أوتجارب المحصول المتقدمه ب أن الهجين [(جـ 83 × جـ80) × جـ 89] × أستر الى تفوق على جميع التر اكيب الور اثية وعلى الاصناف التجارية المنزرعة فى التجربتين وذلك لصفتى محصول القطن الزهر و الثعر بالاضافة الى صفات التيله

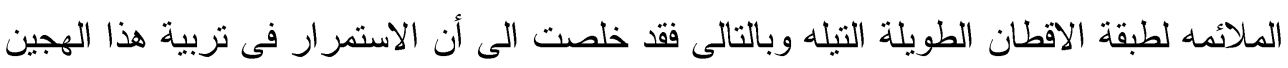
يمكن أن يحقق استباط صنف مستثبلى طويل التيلة وملائم للصناعة المحلية. 